\title{
吻合用膵臓鉗子
}

\author{
大同禮次 郎*
}

\section{Our New Pancreas-forceps for Anastomosis}

\section{Reijiro Daido}

Lecturer, Kyoto Prefectural University of Medicine and head surgeon, Maizuru National Hospital

\section{はじめに}

近時急速に発達した麻酔，輸血，輸液等により長時 間の大手術もも早や何ら危惧することなく行なえるよ うになり，それにつれて外科的侵襲もますます過大に なりつつある現状である。

1900年, Mayo-Robson $か ;$ Billroth, Halstedt 等の 膵切除を報し＜wide>また 1907 年 Coffey が犬ではじめて 膵, 腸吻合術を発表して以来 Sweet, Simon, Dragstadt Whipple, Orr, Child, 等多数の実験的ならびに臨 床的研究がなされ，膵臓外科も長足の進歩をした。

さて, 膵尾側切除は単純結禁のまま放置するも膵液 の漏出さえなければ何ら支障はきたさない，しかしな がら膵頭部切除術に関しては，術者それぞれ独自の方 法により腸管と吻合しているが，かかる場合膆実質を 挫滅するような鉗子は使用し得ず，出血わよび膆液の 流出のまま吻合を行なっているようである，私もしば しば切断端をそのままにして，あろいはまた腸鎾子に て軽く把持して腈腸吻合を試みたが，手術野の污染， 出血に妨げられて時間の損失が大きく，かつまた吻合 が不確実となる危険性をどうしても一掃することがで きない，膵頭部十二指腸全切除術は大手術であり，長 時間を要するので少しでもとれを Cover せんとして 以下の如き膵蔵鍸子を考案した。

\section{鉗子の構造}

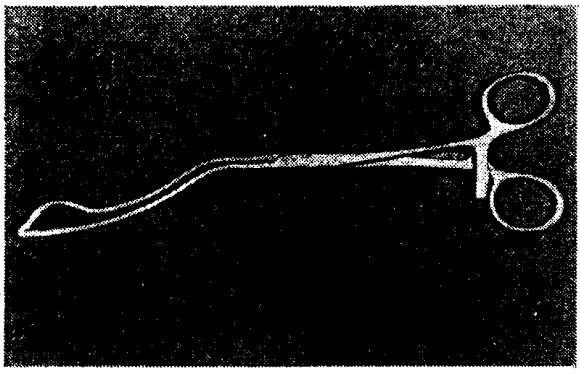

図 1
図1のように極めて弾力性を有するステンレス製の 全長 $22,0 \mathrm{~cm}$, 巾 $0.3 \mathrm{~cm}$, 厚さ $0.1 \mathrm{~cm}$ の緥溝を有する ので，また膵組織を挫㓕するととなくかつ強く把持す るように先端に長径 $2.5 \mathrm{~cm}$, 短径 $1.2 \mathrm{~cm}$ の棈円形を作 り，また深部操作に便なるよう全体的にも少し屈曲し ている.

\section{使用法}

尾側切除術には敢て使用せずとも前述のように強い 圧挫鉗子で膵実質の挫隇を行ない，鉗子を徐々にはず して太い絹系で集束結禁を行なえば十分であるが，頭

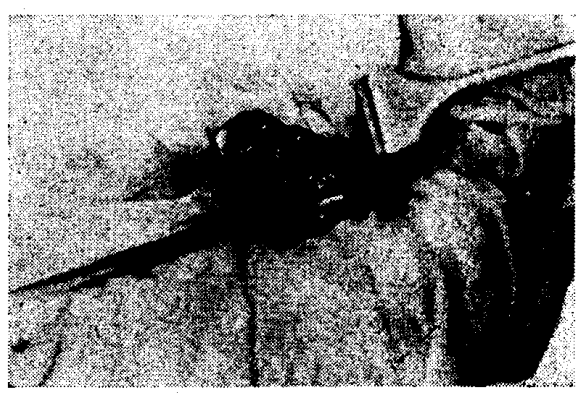

図 2

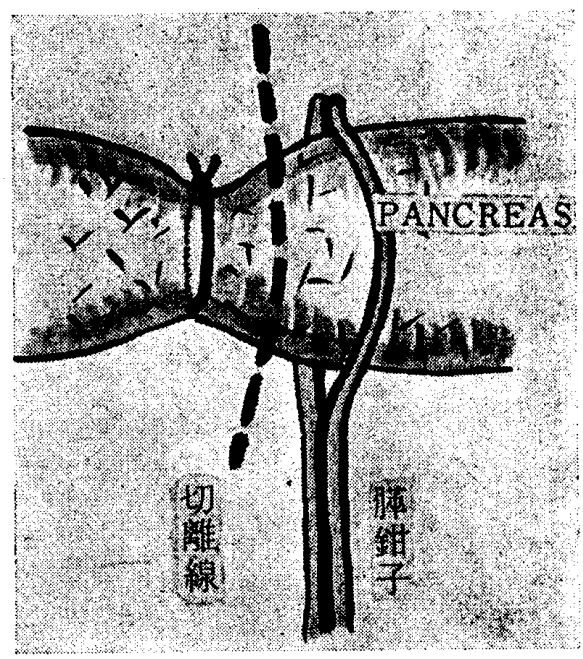

図 3 
側切除を施行する場合は滕腸吻合を絶対必要とするの で以下その使用法を記載すると

図2,3のように十分周囲より腾臟を剝離して鉜子の

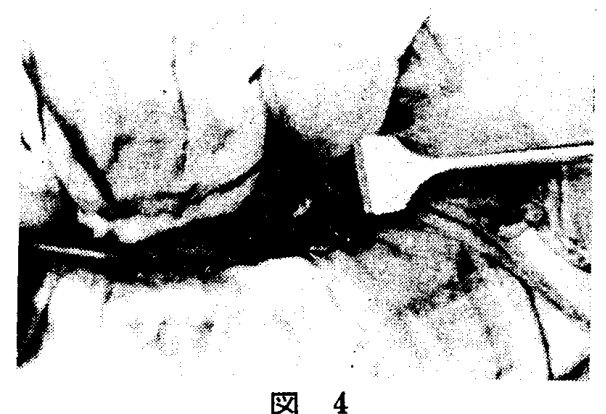

凸部を前方にしてかける，膵血行状態より考え，上下 膵，十二指腸動脈わよび脾動脈より無数の細技が出て いるので十分剶離を進めてる残存膆の血行は極めて良 好である。

てのようにして鉗子より約 $0.5 \mathrm{~cm}$ 残して図 4 の如く 鋭的に切断する. 膵切断端はやっと出血之膵液の漏出 が止まる程度に軟く把握されているので，鎮子を少し 弛めると直ちに血液と膵液の流出を見るので全く理想 的脺把持といえる. この状態で吻合を行なえば，図 5, 6 のように手術野の出血污染は全くなく，十分熟視し て意のままにゆっくりと確実に吻合し得る。

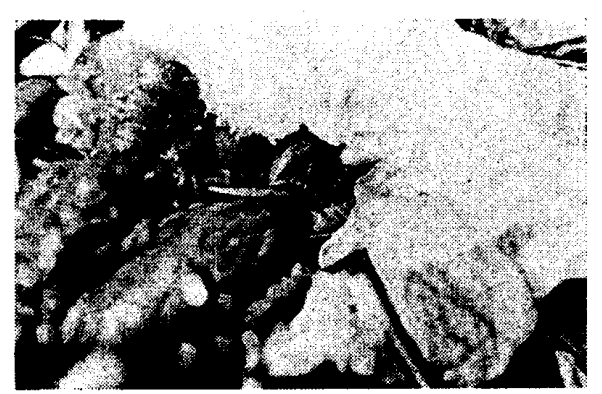

因 5

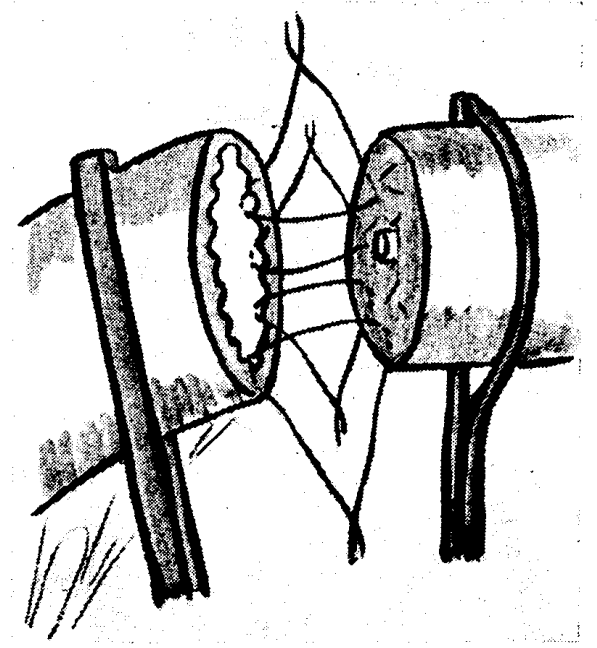

図 6

ての図 5,6は私の行なっている方法で，膵管を少し く剥離分離して周囲膵実質と腸管とを縫着固定し，さ らに繁膜筋㐿縫合にて滕を腸管内に少しく嵌入せしめ るもので, 縫合不全は絶無でありかつ手術操作は簡単 である.

おわりに

膵腸吻合術施行時使用する特殊なる鉜子を考案作製 したが，てれの使用は全く便利であり，かつ十分その 目的を達し得る。なお手術野を出血之膵液の污染より 妨ぎ，膵損傷をも来たさず，手術操作が極めて円滑に なり全く便利である。

本論文の要旨は第15回国立病院㙩養所医学総会に発 表した。

（編集部注） 著者によれば本鎮子は京都市中京区東 洞院二条上ル増田医科器械店で製作している。 